\title{
Eggshell membrane for DNA sexing of the endangered Maleo
}

\section{(Macrocephalon maleo) [version 1; peer review: 1 approved}

\section{with reservations]}

\author{
Pramana Yuda (iD), Andie Wijaya Saputra (iD) \\ Teknobiologi, Universitas Atma Jaya Yogyakarta, Kab. Sleman, DI Yogyakarta, 55281, Indonesia
}

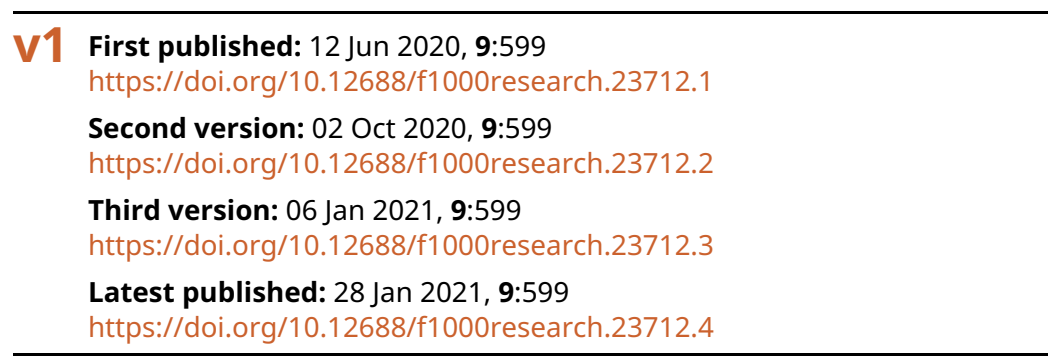

\section{Abstract}

Background: Noninvasive DNA sampling has been applied across many avian genetic studies for a variety of purposes including conservation and management of endangered birds. However, its application in megapodes is still lacking. The previous genetic studies on megapodes used either blood or fresh tissue. Here we present the first demonstration of the use of eggshell membrane for research on endangered Maleo (Macrocephalon maleo).

Methods: We used 24 post-hatched eggshell membranes collected from two different sites, Tambun and Tanjung Binerean, in North Sulawesi, 12 samples in each. Two different DNA extraction methods: alkaline lysis method and gSYNC ${ }^{\mathrm{TM}}$ DNA Extraction Kit were applied. To determine the sex of Maleo, we utilized PCR-based DNA sexing using CHD genes, with the primer set 2550F/2718R.

Results: We successfully extracted all samples; the mean sample concentration was $267.5 \mathrm{ng} / \mu \mathrm{l}$ (range 47-510.5 $\mathrm{ng} / \mu \mathrm{l}$ ) and samples were of high purity (A260/280 ratio $1.85 \pm 0.03$ ). All samples were used to successfully identified sexes, 9 females and 15 males.

Conclusions: Our research clearly illustrates that eggshell membranes can be used for DNA sexing and open the possibility to build noninvasive DNA collections over large spatial scales for population study of endangered birds.

Keywords

eggshell membrane, endangered birds, DNA sexing, , Maleo

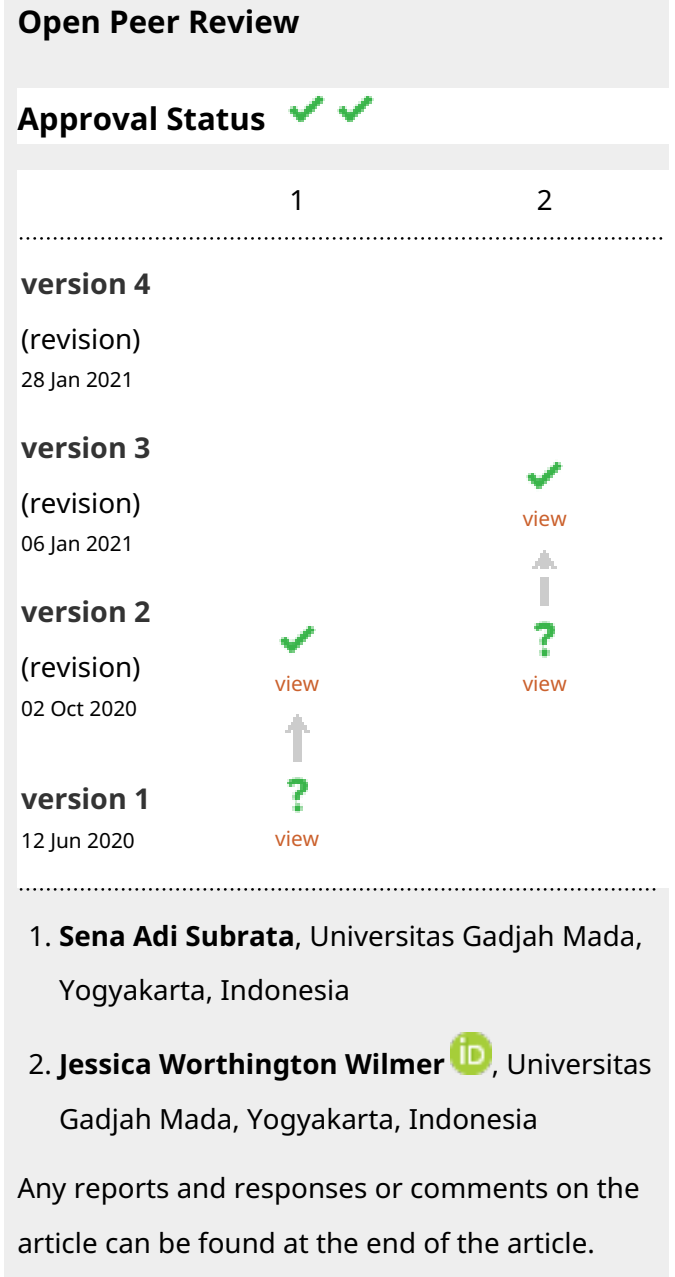


Corresponding author: Pramana Yuda (pramana.yuda@uajy.ac.id)

Author roles: Yuda P: Conceptualization, Formal Analysis, Methodology, Writing - Original Draft Preparation, Writing - Review \& Editing; Saputra AW: Data Curation, Investigation, Project Administration, Writing - Original Draft Preparation

Competing interests: No competing interests were disclosed.

Grant information: This research was funded by the E-PASS Project and WCS-Indonesia Program for fieldwork and collecting samples in North Sulawesi, and by Universitas Atma Jaya Yogyakarta for laboratory work. The research permit was granted by the Indonesia Ministry of Environment and Forestry (SK. 126/KSDAE/SET/KSA.2/3/2018) and complied with the University's Ethics guidelines.

Copyright: ( 2020 Yuda P and Saputra AW. This is an open access article distributed under the terms of the Creative Commons Attribution License, which permits unrestricted use, distribution, and reproduction in any medium, provided the original work is properly cited.

How to cite this article: Yuda P and Saputra AW. Eggshell membrane for DNA sexing of the endangered Maleo (Macrocephalon maleo) [version 1; peer review: 1 approved with reservations] F1000Research 2020, 9:599

https://doi.org/10.12688/f1000research.23712.1

First published: 12 Jun 2020, 9:599 https://doi.org/10.12688/f1000research.23712.1 


\section{Introduction}

Studies on molecular ecology have a great impact on our knowledge on ecology and evolution of animals, i.e. the phylogenetic relationships and systematics of organisms, population genetics, mating systems, micro-evolutionary processes and host-parasite interactions ${ }^{1-4}$. Oftentimes a necessary prerequisite for answering evolutionary or ecological questions is access to a good DNA sample. Birds' blood contains nucleated red blood cells with abundant DNA, making it a preferred source of DNA ${ }^{5}$. However, obtaining blood requires the capture of a bird, which can provoke an increased level of stress and might results in unusual behavior or nest desertion. For example, blood sampling has been reported to reduce annual survival in Cliff Swallows (Petrochelidon pyrrhonota) ${ }^{6}$, although the effects of blood collection in free-living adult and immature birds is not thought to have major negative effects on adult survival, reproductive success, body condition, or behavior?

As an alternative to invasive sampling, researchers have adopted noninvasive sampling methods such as DNA capture from molted feathers ${ }^{8,9}$, feces ${ }^{10,11}$, and egg shell membrane ${ }^{12,13}$. In addition the application of moderately invasive sampling such as buccal swabs ${ }^{14,15}$ has also increased.

Megapodes (family Megapodidae) are a galliform clade, centered in Australasia ${ }^{16}$, that are known for their unique superprecocial behavior ${ }^{17}$. Their ground-living habits, large body size and large egg size make them particularly vulnerable to human persecution, habitat destruction and habitat loss: 11 out of 21 species are now considered endangered or threatened in some form $^{18}$. Given this precarious conservation situation, the application of noninvasive DNA sampling techniques is crucial for megapode birds. Yet previous genetic studies on this family have used either blood ${ }^{19}$ or fresh tissue ${ }^{20}$.

Previously, all megapodes were assumed to be monogamous. The mating system is considered to correlate with sexual selection, with sexually dimorphic birds are non-monogamous and monomorphic birds are monogamous. The evolution of non-monogamous systems in birds was believed to be an adaptive solution to an unbalanced sex ratio ${ }^{21}$. The sex-ratio in Maleo (Macrocephalon maleo) is unknown, but based on previous assumptions, it is expected that the Maleo has an evenly balanced sex ratio. Even though Maleo are slightly sexual dimorphic, the available population data only report total population size and never mention sex ratio. A study on the correlation of incubation temperature and sex ratio of chicks has been carried out in the Australian brush-turkey (Alectura lathami), which revealed that at average temperature the hatched chicks in the proportion of $1: 1$ of male and female chicks ${ }^{22}$.

The purpose of our study was to determine whether the eggshell membrane of the endangered Maleo, a monotypic genus within the megapodes, could be successfully extracted and amplified for DNA sexing. Adult male and female Maleo are morphologically slightly different, but the chicks are not. To determine the sex in Maleo chicks, vent sexing has been conducted. Base on cloaca size and shape, a one-day-old male Maleo chick cloaca is bigger $(3.96 \pm 0.11 \mathrm{~cm})$ and rounded, than the female cloaca $(3.20 \pm 0.10 \mathrm{~cm})$, which is more oval in shape. The concentration of estrogen in female birds was also higher ${ }^{23}$. Until recently, no molecular technique has been applied for sex determination of Maleo.

Maleo are endemic to Sulawesi, Indonesia ${ }^{24,25}$. The bird is a burrow-nesting megapode that incubates its eggs in communal nesting sites on beaches (coastal nesting grounds) and in soil heated by volcanic activity mostly at inland localities. Due to its small, severely fragmented population and continued rapid decline, the International Union for Conservation of Nature has classified Maleo as an endangered species ${ }^{26}$. Among the major threats are the over-exploitation of eggs and loss of connectivity between forest and nesting grounds ${ }^{27}$. To minimize these threats at some nesting grounds, conservation programs are currently removing eggs and hatching them in safer, semi-natural hatcheries, built close to the nesting grounds. These facilities provide an opportunity to collect noninvasive DNA samples from the eggshell membrane left in the soil or brought to the soil surface by the hatched Maleo.

\section{Methods}

Study sites and genetic sampling

Post-hatched egg-shell membranes were collected from seminatural hatcheries of Maleo at two different nesting grounds: an inland geothermal heated nesting ground at Tambun (Bogani Nani Wartabone National Parks and a sun-heated sand beach nesting ground at Tanjung Binerean, North Sulawesi, Indonesia (Figure 1). All samples were collected from $4^{\text {th }}$ April until $1^{\text {st }}$ May 2018. To prevent post-sampling contamination, each sample was placed separately in a zip-lock plastic bag and stored in silica gel for delivery to laboratory. The samples were stored at $-40^{\circ} \mathrm{C}$ until DNA extraction were conducted.

\section{DNA extraction}

We used two different DNA extraction methods: the alkaline lysis method and gSYNCTM DNA Extraction Kit (Genaid). For the alkaline lysis method, we followed the recommended procedure for rapid preparation of mouse tails or nail lysates suitable for amplification using DNA polymerase from hyperthermophilic archaeon Pyrococcus kodakaraensis (KOD FX Neo 1103; TOYOBO Co. Ltd.). The eggshell membrane (20-25 mg; mostly with dry allantois blood vessel) was grinded using a micro-pestle in a $1.5 \mathrm{~mL}$ microcentrifuge tube; next, $180 \mu \mathrm{L}$ $\mathrm{NaOH}(50 \mathrm{mM})$ was added, the suspension mixed thoroughly by vortexing and then incubated at $90^{\circ} \mathrm{C}$ in water-bath for 10-29 min. Following this, $20 \mu \mathrm{L}$ Tris-HCl (1 M, pH 8.0) was added and the tube was vortexed thoroughly, then centrifuged at 12,000 RPM for $5 \mathrm{~min}$. Supernatant was removed to new $1.5 \mathrm{~mL}$ microtube and store at freezer until used for PCR.

Meanwhile the protocol for gSYNCTM DNA Extraction Kit (Genaid) followed the provided user manual with little modifications. The eggshell membrane $(25 \mathrm{mg}$; mostly with dry allantois blood vessel) was grinded using a micro-pestle in a $1.5 \mathrm{~mL}$ 


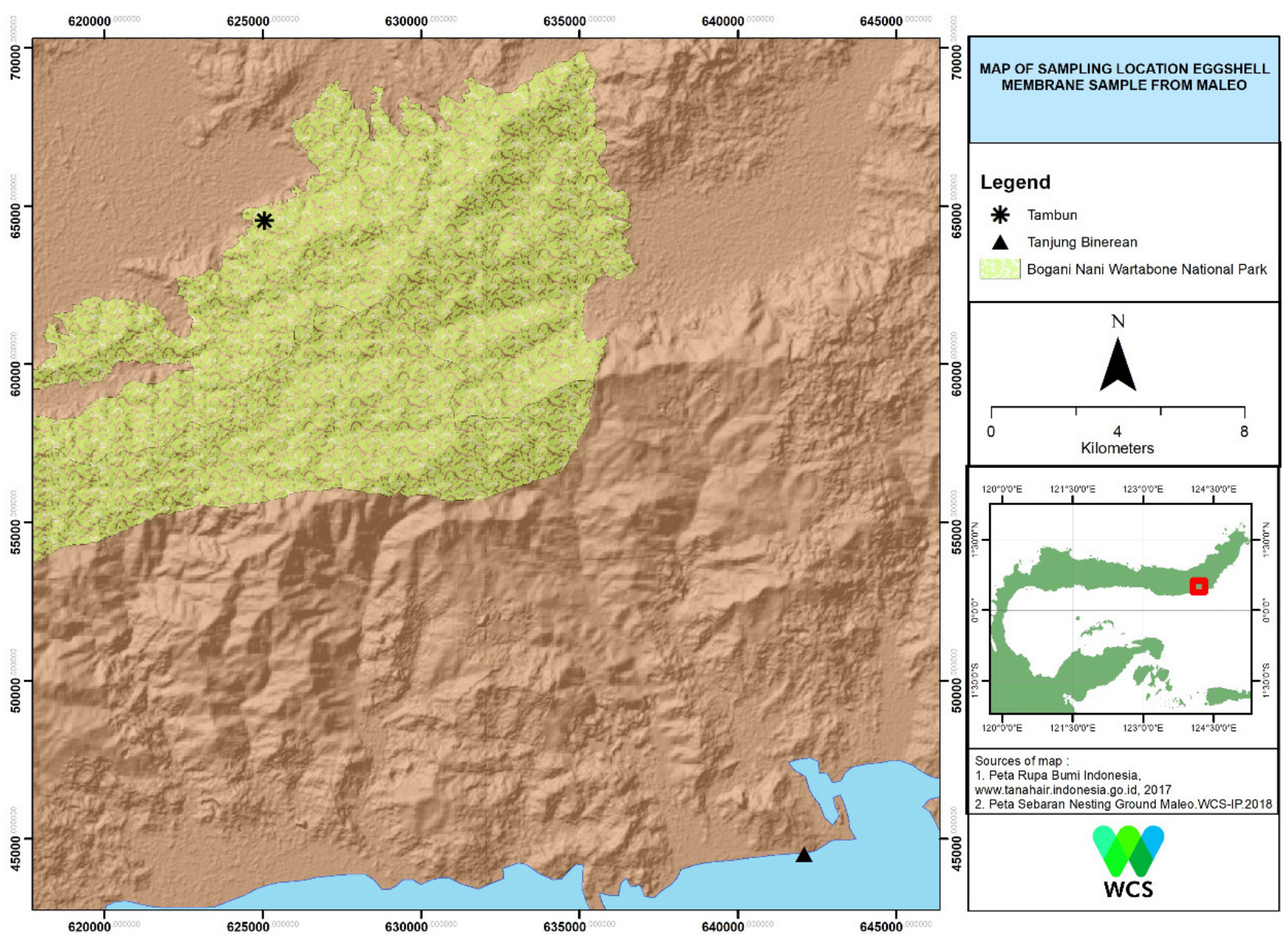

Figure 1. Sampling sites of eggshell membrane of Maleo (Macrochepalon maleo) in North Sulawesi, Indonesia.

microcentrifuge tube; $300 \mu \mathrm{l}$ GST Buffer (Tris, SDS) and $30 \mu \mathrm{l}$ Proteinase K $(10 \mathrm{mg} / \mathrm{ml})$ was added to the sample mixture, mixed thoroughly by vortexing and incubated at $60^{\circ} \mathrm{C}$ in waterbath overnight or until the tissue was lysed completely. Next, $200 \mu \mathrm{l}$ GSB Buffer was added to the sample mixture, mixed thoroughly by pulse-vortexing and incubated at $70^{\circ} \mathrm{C}$ for $10 \mathrm{~min}$. After this, $200 \mu \mathrm{l}$ ethanol $(100 \%)$ was added to the sample mixture, which was mixed thoroughly by pulse-vortexing and brief spinning of the tube to remove drops from the inside of the lid. Next, a GS Column was placed in a Collection Tube and the mixture (including any precipitate) was carefully transferred to the GS Column, which was centrifuged at 14,000 RPM for 1 min then the GS Column was placed in a new Collection Tube. Following this, $400 \mu \mathrm{lW} 1$ Buffer was added to the GS Column and centrifuged at 14,000 RPM for $1 \mathrm{~min}$ then flow-through was discarded. Next, $750 \mu \mathrm{l}$ Wash Buffer was added to the GS Column, centrifuged at full speed for $1 \mathrm{~min}$, then the flow-through was discarded, the tube centrifuged at 14,000 RPM for an additional $3 \mathrm{~min}$ to dry the column, $50 \mu \mathrm{l}$ of preheated Elution Buffer (pH 7.5-9.0) added to the membrane of the GS Column. The GS Column was then left to stand for $3 \mathrm{~min}$, following a final centrifugation at full speed for 2 min to elute the DNA.
The eluded DNA $(1 \mu \mathrm{l})$ was quantified using NanoVue Plus ${ }^{\mathrm{TM}}$ (Biochrom, Harvard Bioscience, Inc), at A260 nm. The 260/280 nm absorbance ratio was also measured to give an indication of purity of the DNA. Pure DNA has expected ratios of $1.7-1.9$.

\section{DNA sexing}

To determine the sex of Maleo, we applied PCR based DNA sexing by using CHD genes, with the primer set $2550 \mathrm{~F} / 2718 \mathrm{R}^{28}$. PCR used a $10 \mu \mathrm{l}$ total volume containing template DNA (genomic DNA or lysate), $1.2 \mu \mathrm{l}$ sterile $\mathrm{dH}_{2} \mathrm{O}, 5 \mu \mathrm{l} 2 \mathrm{x}$ PCR buffer KOD FX Neo, $2 \mu \mathrm{l}$ dNTPs $(2 \mathrm{mM})$, (TOYOBO Co. Ltd.), $0.3 \mu$ Primer 2550F (10 $\mu \mathrm{M}$; 5'-GTT ACT GAT TCG TCT ACG AGA-3'), and $0.3 \mu \mathrm{l}$ Primer 2718R (10 $\mu \mathrm{M}$; 5'-ATT GAA ATG ATC CAG TGC TTG-3', ${ }^{28}$ ), and 0.2 U KOD polymerase enzyme. PCR was carried out in a VeritiTM 96-well thermal cycler (Applied Biosystems $\left.{ }^{\mathrm{TM}}\right)$. For genomic DNA templates, the following profile was used: 1 cycle at $94^{\circ} \mathrm{C}$ for $2 \mathrm{~min}$ followed by 35 cycles of $98^{\circ} \mathrm{C}$ for $10 \mathrm{sec}, 53^{\circ} \mathrm{C}$ for $30 \mathrm{sec}$ and $68^{\circ} \mathrm{C}$ for $45 \mathrm{sec}$; , and a final extension at $68^{\circ} \mathrm{C}$ for 7 minutes. For lysate as DNA template, the PCR profiles was the same for DNA genome, except that it was run for more cycles $(40 \mathrm{x})$. We 
employed eggshell membrane from female domestic chicken as positive control, and tube without sample as negative one.

Amplification of CHD Genes were resolved on a $2 \%$ agarose gel. Electrophoresis was conducted using TAE $(0.5 \times)$ buffer, stained by ethidium bromide (1\%), at $100 \mathrm{~V}$ for 30 minutes; and $5 \mu \mathrm{l}$ PCR product was mixed with $1 \mu \mathrm{l}$ loading dye. After finish, the gel was visualized and analyzed on Gel Logic 200 Imaging System and Kodak Molecular Imaging Software. To confirm that the amplified fragments were the CHD genes, the PCR products of one male and one female sample, respectively, were sequenced. The gels were cut on upper and lower bands for female samples and the single band for male sample, then purified for sequencing. The sequence reactions were carried for both direction in sequencing services laboratory provided by $1^{\text {st }}$ BASE Laboratories (Apical Scientific Sdn Bhd, Malaysia). The sequences were check and edited manually on Bioedit version 7.0.5.3 (Hall, 1999) and Chromas versi 2.6.5 (Technelysium Pty Ltd). Sequence similarity was probed using NCBI BLAST (Zhang et al., 2000).

\section{Statistical analysis}

Mann-Whitney U-test (at a significance level of 95\%) was performed to assess the DNA concentration differences which were collected on Tanjung Binerean and Tambun. Analysis was performed using SPSS v17.

\section{Results}

All eggshell membranes were successfully extracted, with mean DNA concentrations around $267.5 \mathrm{ng} / \mu \mathrm{l}$ (range $47-510.5 \mathrm{ng} / \mu \mathrm{l}$ ). The average DNA concentration extracted from eggshell membrane collected from coastal nesting grounds (Tanjung Binerean: $213 \pm 179 \mathrm{ng} / \mu \mathrm{l}$,) was significantly lesser than of that of inland nesting grounds (Tambun: $322 \pm 153 \mathrm{ng} / \mu \mathrm{l}, \mathrm{p}=0.004$; Data Supp.1). These results demonstrate that all samples were adequate for further PCR based analysis.

The 260/280 $\mathrm{nm}$ absorbance ratio of all samples ranged from 1.81 to 1.89 , with an average of $1.85( \pm 0.03)$. Meanwhile the average for Tambun and Tanjung Binerean samples were, respectively, $1.85( \pm 0.03)$ and $1.84( \pm 0.01)$; Table 1).

\section{Table 1. Concentrations and purity of DNA extracted from eggshell membrane of Maleo (Macrochepalon maleo).}

\begin{tabular}{|c|c|c|c|c|}
\hline No. & Location & Sample Code & Purity (A260/A280 Ratio) & Concentration $(\mathrm{ng} / \mu \mathrm{l})$ \\
\hline 1 & Tambun & MT03 & 1.848 & 127.5 \\
\hline 2 & Tambun & MT02 & 1.821 & 204.0 \\
\hline 3 & Tambun & MT17 & 1.879 & 280.0 \\
\hline 4 & Tambun & MT18 & 1.845 & 302.5 \\
\hline 5 & Tambun & MT10 & 1.822 & 308.0 \\
\hline 6 & Tambun & MT04 & 1.881 & 308.5 \\
\hline 7 & Tambun & MT12 & 1.829 & 342.0 \\
\hline 8 & Tambun & MT06 & 1.869 & 349.5 \\
\hline 9 & Tambun & MT07 & 1.898 & 364.5 \\
\hline 10 & Tambun & MT19 & 1.832 & 381.0 \\
\hline 11 & Tambun & MT20 & 1.846 & 383.0 \\
\hline 12 & Tambun & MT15 & 1.887 & 510.5 \\
\hline \multicolumn{3}{|c|}{ Average (Tambun) } & 1.855 & 321.75 \\
\hline 13 & Tanjung Binerean & MB09 & 1.880 & 47.0 \\
\hline 14 & Tanjung Binerean & MB11 & 1.859 & 72.5 \\
\hline 15 & Tanjung Binerean & MB10 & 1.813 & 155.0 \\
\hline 16 & Tanjung Binerean & MB08 & 1.818 & 174.4 \\
\hline 17 & Tanjung Binerean & MB04 & 1.839 & 183.0 \\
\hline 18 & Tanjung Binerean & MB07 & 1.844 & 206.5 \\
\hline 19 & Tanjung Binerean & MB12 & 1.858 & 209.0 \\
\hline 20 & Tanjung Binerean & MB05 & 1.841 & 232.0 \\
\hline 21 & Tanjung Binerean & MB02 & 1.821 & 249.5 \\
\hline 22 & Tanjung Binerean & MB03 & 1.852 & 250.0 \\
\hline 23 & Tanjung Binerean & MB06 & 1.816 & 286.0 \\
\hline 24 & Tanjung Binerean & MB01 & 1.893 & 495.0 \\
\hline \multicolumn{3}{|c|}{ Average (Tanjung Binerean) } & 1.845 & 213.3 \\
\hline \multicolumn{3}{|c|}{ Average (all samples) } & 1.850 & 267,5 \\
\hline
\end{tabular}


This result suggested good purity of DNA extracted from eggshell samples. However. gel visualization of extracted DNA showed smears in all samples (Figure 2), pointing to some DNA degradation.

\section{Sex determination}

Out of 24 samples in which extracted DNA was used as a template, one did not amplify. Meanwhile all samples based on lysate were successfully amplified. There was complete agreement in gender determination across all Maleo samples that were run with different DNA template (Figure 3). Females showed two bands (545 bp and $395 \mathrm{bp}$ ), whereas males exhibited one band $(545 \mathrm{bp})$. Three sequences of CHD1 genes have been deposited in GenBank (accession numbers MT074328, MT074329 and MT074330). Sequence similarity searches on the upper band revealed a match with CHD-Z genes of other bird species (i.e. Anser cygnoides, Anser reevesii, Anas penelope). Meanwhile the lower band matched CHD-W submissions of other birds (i.e. Gallus gallus, Crossoptilon mantchuricum, Syrmaticus reevesii).

In total 9 samples were identified as females and 15 were males (Table 2). Based on this limited sample, the sex ration of Maleo's chicks in Tambun and Tanjung Binerean is biased towards males. The sex ratio males to females was 1.6 , and significantly different from the hypothetic sex ratio 1:1 for Maleo.

\section{Discussion}

This study has demonstrated the first successful DNA isolation from eggshell membranes of a megapode bird. Our success rate (100\%) compares favorably to that of previous avian eggshell membrane studies of Black-tailed Godwits (Limosa limosa), which also successfully extracted DNA from all 47 eggshell membranes ${ }^{13}$. The freshness of the samples might be one of the determinant factors of DNA extraction success. Our samples were relatively fresh, extracted 5-15 days after collection and kept in the freezers until extraction, with no concomitant extraction failure and high purity $(1.85 \pm 0.03)$ and concentration $(267.5 \mathrm{ng} / \mu \mathrm{l})$ of DNA.

PCR amplification of CHD genes succeeded in $96 \%$ of the eggshell membrane samples, with only one eggshell membrane isolate out of 24 failing to amplify. However, using lysate as DNA template for PCR resulted in $100 \%$ amplifications across 24 samples. This result show that eggshell membrane isolates yielded DNA with little amplification problems. Compared to blood DNA isolates, eggshell membrane DNA isolates of Blacktailed Godwits (Limosa limosa) also yielded fewer amplification problems $^{13}$. One eggshell membrane DNA isolate out of 21
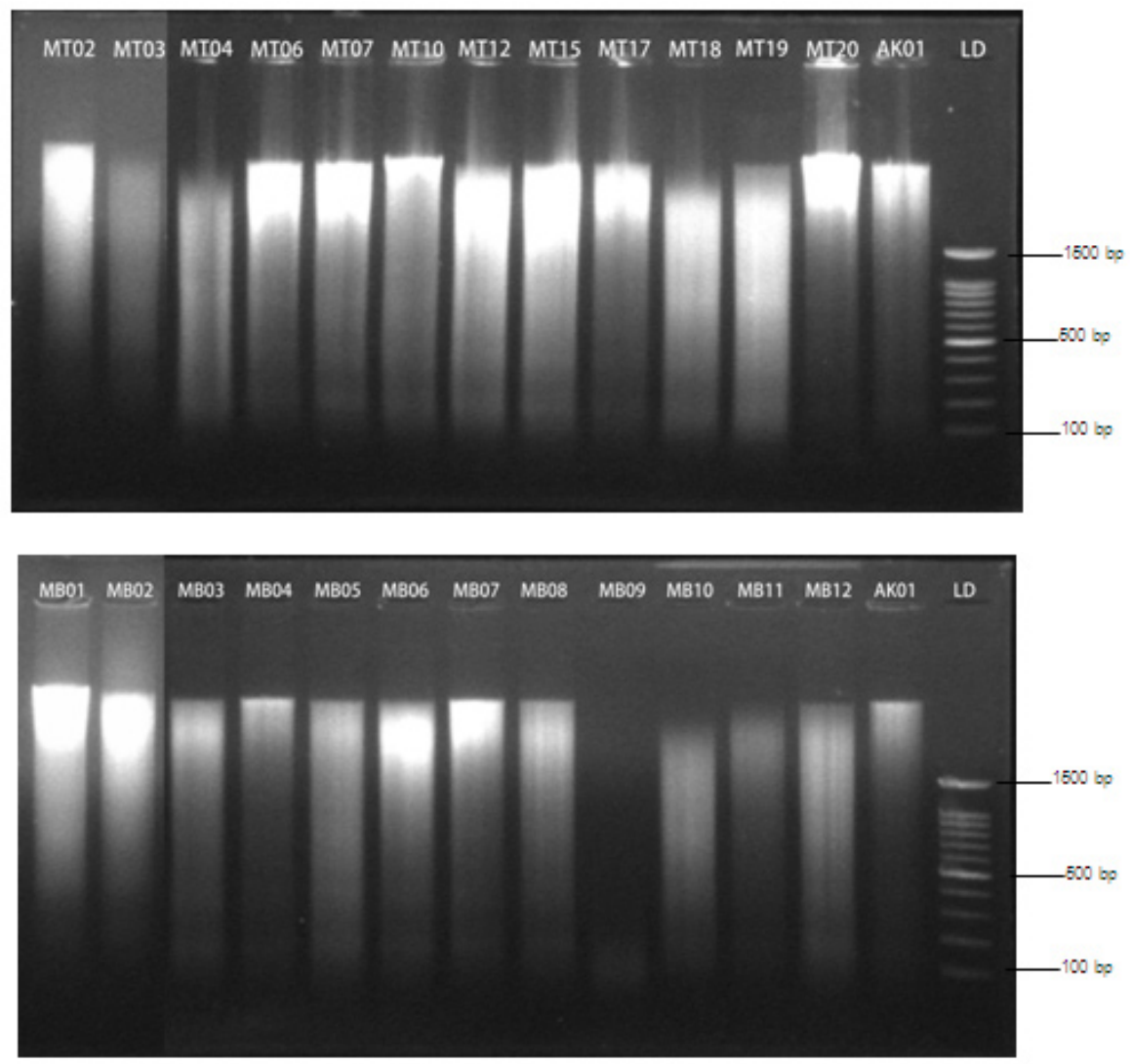

Figure 2. Gel visualizing DNA degeneration of eggshell membrane samples. Above: Tambun; Below: Tanjung Binereaan; LD: 100 bp DNA Ladder (SMOBiO); AK01: domestic chicken eggshell membrane. 

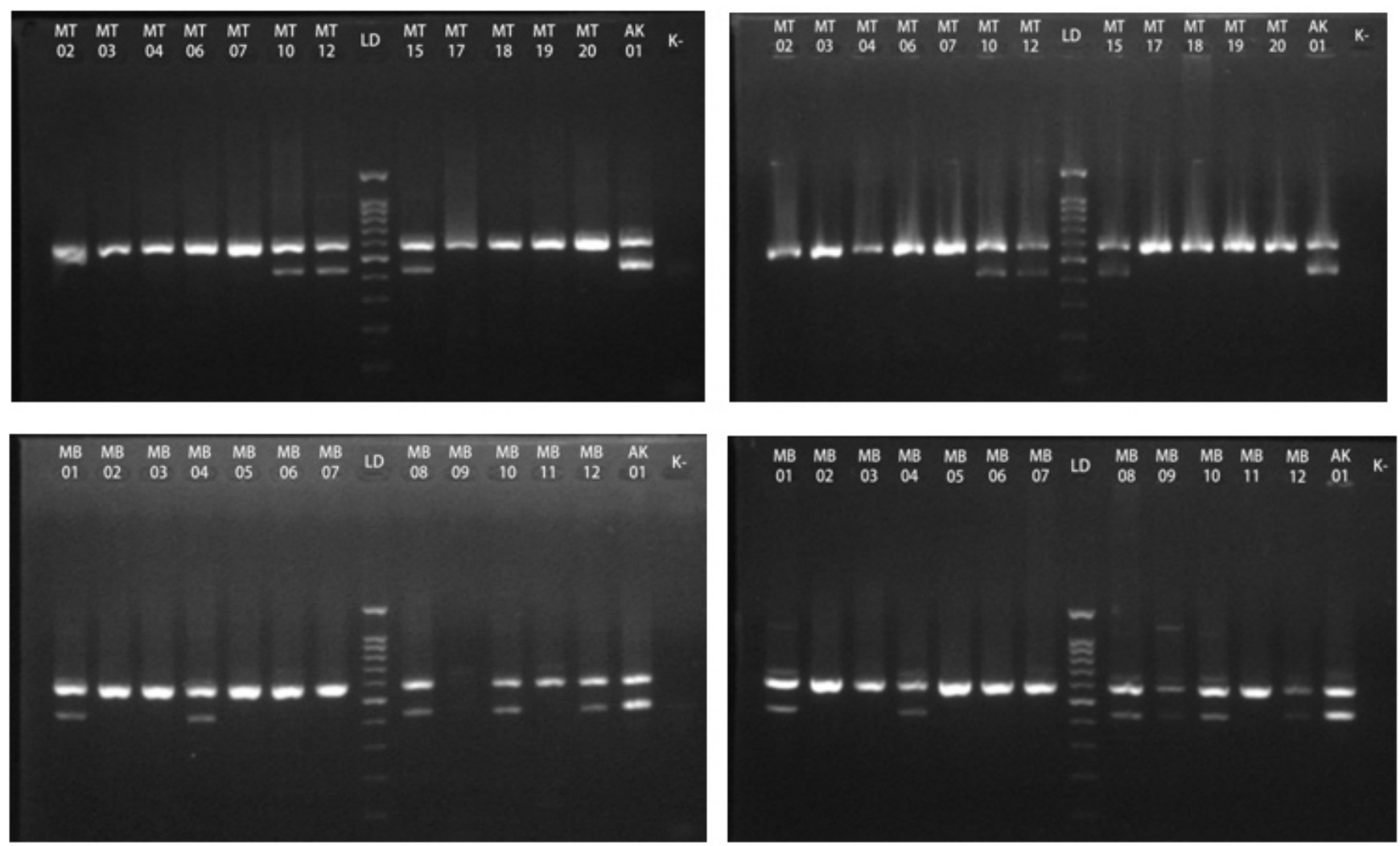

Figure 3. Gel visualizing of CHD-genes amplification of Maleo using extracted DNA (left) and Lysate (right) for molecular sexing of Tambun (above) and Tanjung Binerean (below) samples. AK1, positive control, female chicken; $\mathrm{K}$, negative control, no template.

Table 2. Identified sex of Maleo (Macrocepalon maleo) based on molecular sexing with different templates.

\begin{tabular}{|c|l|l|l|}
\hline \multirow{2}{*}{ No. } & Sample Code & \multicolumn{2}{|c|}{ Template } \\
\hline 1 & MT02 & Male & Male \\
\hline 2 & MT03 & Male & Male \\
\hline 3 & MT04 & Male & Male \\
\hline 4 & MT06 & Male & Male \\
\hline 5 & MT07 & Male & Male \\
\hline 6 & MT10 & Female & Female \\
\hline 7 & MT12 & Female & Female \\
\hline 8 & MT15 & Female & Female \\
\hline 9 & MT17 & Male & Male \\
\hline 10 & MT18 & Male & Male \\
\hline 11 & MT19 & Male & Male \\
\hline
\end{tabular}

\begin{tabular}{|l|l|l|l|}
\hline \multirow{2}{*}{ No. } & Sample Code & \multicolumn{2}{|c|}{ Template } \\
\hline 12 & MT20 & Male & Male \\
\hline 13 & MB01 & Female & Female \\
\hline 14 & MB02 & Male & Male \\
\hline 15 & MB03 & Male & Male \\
\hline 16 & MB04 & Female & Female \\
\hline 17 & MB05 & Male & Male \\
\hline 18 & MB06 & Male & Male \\
\hline 19 & MB07 & Male & Male \\
\hline 20 & MB08 & Female & Female \\
\hline 21 & MB09 & - & Female \\
\hline 22 & MB10 & Female & Female \\
\hline 23 & MB11 & Male & Male \\
\hline 24 & MB12 & Female & Female \\
\hline
\end{tabular}


and 3 samples of Black-tailed Godwit (Limosa limosa) did not amplify for 2 and 5 of the 11 microsatellite loci. The amplification success rates was $99.1 \%^{13}$. Meanwhile the success rate of eggshell membrane of Sage Grouse (Centrocercus uropihasianus) for DNA sexing was only $55.6 \%^{12}$.

This study demonstrates that hatched eggshell membrane provides useful noninvasive DNA material as an alternative to invasive sampling in sex determination studies of Maleo. Information of the sex of the hatched eggs are important to understand demographic issues, such as the demographic consequences of offspring sex ratio bias or whether there is any sex-specific mortality or dispersal. Furthermore, this information is very important for translocation programs of endangered species, including Maleo.

This study provides additional evidence that noninvasive DNA samples yield reliable results and eliminating the need for capture and invasive sampling. Collection of post-hatched eggshell membrane of Maleo, and other megapodes does not require specific skills. This noninvasive DNA sampling also open the possibility to build participation of local community or local conservation area staff on DNA collections over large spatial scales. Furthermore, the collected samples provide sufficient samples required for population and other ecological and evolutionary study of endangered bird species.

\section{Data availability}

Underlying data

NCBI GenBank: Macrocephalon maleo isolate MT10-FTB UAJY_01 chromo-helicase DNA binding protein (CHDZ) gene, partial cds. Accession number MT074328.
NCBI GenBank: Macrocephalon maleo isolate MB01-FTB UAJY_02 chromo-helicase DNA binding protein (CHDZ) gene, partial cds. Accession number MT074329.

NCBI GenBank: Macrocephalon maleo isolate MT10-FTB_ UAJY_03 chromo-helicase DNA binding protein (CHDZ) gene, partial cds. Accession number MT074330.

Mendeley Data: Eggshell membrane for DNA sexing of the endangered Maleo (Macrocephalon maleo). http://doi.org/10.17632/ mjp5n9pcj3.

This project contains the following underlying data:

- Electrophoresis photos. (Folder containing photos of DNA extraction and PCR sexing gels.)

- $\quad$ Sequences. (Folder containing raw sequencing files.)

Data hosted with Mendeley Data are available under the terms of the Creative Commons Attribution 4.0 International license (CC-BY 4.0).

\section{Acknowledgements}

We would like to acknowledge Elisabeth Purastuti and Hanom Basri (EPASS Project), Iwan Hunowu and Alfons Patandung (WCS-IP Sulawesi) and Bogani Nani Wartabone National Park staff for their support during collecting samples. We also thank to Harry Marshal and Frank E. Rheint for reviewing the manuscript.
1. Zink RM, Blackwell-Rago RC: Species limits and recent population history in the Curve-billed Thrasher. Condor. 2000; 102(4): 881-6. Publisher Full Text

2. Yuda P: High Prevalence Level of Avian Malaria in the Wild Population of the Java Sparrow. Biota. 2009; 14(3): 198-200. Reference Source

3. Küpper C, Augustin J, Kosztolányi A, et al:: Kentish versus Snowy Plover: phenotypic and genetic analyses of Charadrius alexandrinus reveal divergence of Eurasian and American subspecies. Auk. 2009; 126(4): 839-52. Publisher Full Text

4. Yuda P: Detection of avian malaria in wild birds at Trisik Beach of Yogyakarta, Java (Indonesia). Ann Parasitol. 2019; 65(2): 171-5 PubMed Abstract | Publisher Full Text

5. Colquitt BM, Mets DG, Brainard MS: Draft genome assembly of the Bengalese finch, Lonchura striata domestica, a model for motor skill variability and learning. Gigascience. Oxford University Press; 2018; 7(3): 1-6. PubMed Abstract | Publisher Full Text | Free Full Text

6. Brown MB, Brown CR: Blood sampling reduces annual survival in Cliff Swallows (Petrochelidon Pyrrhonota). Auk. 2009; 126(4): 853-61. Publisher Full Text

7. Sheldon LD, Chin EH, Gill SA, et al.: Effects of blood collection on wild birds: An update. J Avian Biol. 2008; 39(4): 369-78. Publisher Full Text

8. Miño Cl, Del Lama SN: Molted feathers as a source of DNA for genetic studies in Waterbird Populations. Waterbirds. 2009; 32(2): 322-9. Publisher Full Tex

9. Rudnick JA, Katzner TE, Bragin EA, et al:: Species identification of birds through genetic analysis of naturally shed feathers. Mol Ecol Notes. 2007; 7(5):

\section{7-62.}

Publisher Full Text

10. Rytkönen S, Vesterinen EJ, Westerduin C, et al:: From feces to data: A metabarcoding method for analyzing consumed and available prey in a bird-insect food web. Ecol Evol. 2019; 9(1): 631-9. PubMed Abstract | Publisher Full Text | Free Full Text

11. Joo S, Park S: Identification of bird species and their prey using DNA barcode on feces from Korean traditional village groves and forests (maeulsoop). Animal Cells Syst (Seoul). 2012; 16(6): 488-97. Publisher Full Text

12. Bush $\mathrm{KL}$, Vinsky MD, Aldridge $\mathrm{CL}$, et al:: A comparison of sample types varying in invasiveness for use in DNA sex determination in an endangered population of greater Sage-Grouse (Centrocercus uropihasianus). Conserv Genet. 2005; 6(5): 867-70. Publisher Full Text

13. Trimbos KB, Broekman J, Kentie R, et al:: Using eggshell membranes as a DNA source for population genetic research. J Ornithol. 2009; 150(4): 915-20. Publisher Full Text

14. Handel CM, Pajot LM, Talbot SL, et al:: Use of Buccal Swabs for Sampling DNA from Nestling and Adult Birds. Wildl Soc Bull. 2006; 34(4): 1094-100. Publisher Full Text

15. Vilstrup JT, Mullins TD, Miller MP et al: A simplified field protocol for genetic sampling of birds using buccal swabs. Wilson J Ornithol. 2018; 130(1): 326-34. Publisher Full Text

16. Elliott A: Megapodes (Megapodiidae). (eds.) del Hoyo J, Elliott A, Sargatal J, Christie DA, de Juana E. editors. Handbook of the Birds of the World Alive. Barcelona.: Lynx Edicions; 2020.

Publisher Full Text 
17. Starck JM, Ricklefs RE: editors. Avian Growth and Development Evolution within the Altrical-Precocial Spectrum. Oxford University Press, UK; 1998. Reference Source

18. IUCN: The IUCN Red List of Threatened Species. Version. 2019-3. 2020. Reference Source

19. Budiarsa IM, Artama IWT, Sembiring L, et al.: Diversitas genetik burung Maleo (Macrocephalon maleo) berdasarkan sekuen gen dehydrogenase sub-Unit 2 (ND2) mitokondria. Berk Penelit Hayati Ed Khusus. 2009; 3B: (June): (ND2) $11-5$.
Reference Source

20. Birks SM, Edwards SV: A phylogeny of the megapodes (Aves: Megapodiidae) based on nuclear and mitochondrial DNA sequences. Mol Phylogenet Evol. 2002; 23(3): 408-21.

PubMed Abstract | Publisher Full Tex

21. Jones DN: An evolutionary approach to megapode mating systems. Zool Verh 1992; 278: 33-42.

Reference Source

22. Göth A, Booth D: Temperature-dependent sex ratio in a bird. Biol Lett. 2005 1(1): 31-3

PubMed Abstract | Publisher Full Text | Free Full Text

23. Widnyana IGNP, Sundu B, Tanari M: Sex detection in Maleo Bird
(Macrocephalon Maleo Sal Muller 1846) nurtured in ex-situ conservation through body morphological and hormonal studies. Int J Vet Sci Agric Res. 2019; 1(2): 17-22.

Reference Source

24. Elliott A, Kirwan GM: Maleo (Macrocephalon maleo). In: del Hoyo J, Elliott A, Sargatal, J., Christie, D.A. \& de Juana E (eds. )., editors. Handbook of the Birds of the World Alive. Lynx Edicions, Barcelona. 2020.

Publisher Full Text

25. Yuni LPEK, Yuda IP: The Island Biogeography of Wallacea and Krakatoa Island. In: Reference Module in Earth Systems and Environmental Sciences. Elsevier. 2019. Publisher Full Text

26. BirdLife International: Threatened Birds of Asia: the BirdLife International Red Data Book. Cambridge, UK: BirdLife International. 2001.

Publisher Full Text

27. Froese GZL, Mustari AH: Assessments of Maleo Macrocephalon maleo nesting grounds in South-east Sulawesi reveal severely threatened populations. Bird Conserv Int. 2019; 29(4): 497-502.

Publisher Full Text

28. Fridolfsson AK, Ellegren $\mathrm{H}$ : A simple and universal method for molecular sexing of non-ratite birds. J Avian Biol. 1999; 30: 116-21.

Publisher Full Text 


\section{Open Peer Review}

\section{Current Peer Review Status: ?}

\section{Version 1}

Reviewer Report 08 September 2020

https://doi.org/10.5256/f1000research.26162.r69914

(C) 2020 Subrata S. This is an open access peer review report distributed under the terms of the Creative Commons Attribution License, which permits unrestricted use, distribution, and reproduction in any medium, provided the original work is properly cited.

\section{Sena Adi Subrata}

Department of Forest Resource Conservation, Faculty of Forestry, Universitas Gadjah Mada, Yogyakarta, Indonesia

In general, the article provided a new finding that never been reported, and discussed possible contribution of the finding to the species conservation. However, there was unclear information particularly in the methods section that should be resolved before the article can be published.

Here is my suggestion:

In the introduction section, a correction is needed on the family name of the bird.

In methods section, particularly genetic sampling, a further explanation is required regarding sample collection: how to collect the membranes? How old is the samples? Furthermore, the author should refer supernatant as lysate. Volume and DNA concentration should be explicitly mentioned when describing PCR condition. Method of sex determination of positive control (egg shell membrane of chicken) should be described. Report of statistical test should be removed because it was meaningless without argument in the discussion.

The author should mention and analyze a failed sample in the result and discussion sections. Most likely it correlated with DNA quality and quantity. When comparing sex ratio, it should be done in the same way.

In the discussion section, particularly when discussion freshness of a sample, the author should provide data on the old of the sample. In the Figure 3, a scale indicating length of the amplicon/ladder should is required.

Is the work clearly and accurately presented and does it cite the current literature? Yes

Is the study design appropriate and is the work technically sound? 
Partly

Are sufficient details of methods and analysis provided to allow replication by others? Partly

If applicable, is the statistical analysis and its interpretation appropriate?

No

Are all the source data underlying the results available to ensure full reproducibility? Partly

Are the conclusions drawn adequately supported by the results?

Partly

Competing Interests: No competing interests were disclosed.

Reviewer Expertise: Wildlife molecular ecologist

I confirm that I have read this submission and believe that I have an appropriate level of expertise to confirm that it is of an acceptable scientific standard, however I have significant reservations, as outlined above.

Author Response 28 Sep 2020

\section{Pramana Yuda}

Thank you for reviewing our article and some valuable recommendations for improvement. We have incorporated the correction and recommendations in our revised article.

Family name was corrected

In method section we added description of sample age, collection technique, the volume and concentration of the DNA, and the more description on positive control for sex determination. We also removed the statistical test.

Failed sample (MB09) in sex determination was added in 'Sex determination' section and discussion.

Length of amplicon was added in Figure 3

The description on age and freshness of samples were added in method and discussion sections.

Competing Interests: No competing interests were disclosed. 
The benefits of publishing with F1000Research:

- Your article is published within days, with no editorial bias

- You can publish traditional articles, null/negative results, case reports, data notes and more

- The peer review process is transparent and collaborative

- Your article is indexed in PubMed after passing peer review

- Dedicated customer support at every stage

For pre-submission enquiries, contact research@f1000.com 